\title{
CHEMICAL CONSTITUENTS OF SOME SPECIES OF HOLOTHURIANS FOUND IN SRI LANKA
}

\author{
RAJESWARY MAGESWARAN AND VASEETHA BALAKRISHNAN \\ Department of Chemistry, University of Jaffna, Jaffna, Sri Lanka.
}

(Date of receipt : 30 January 1985)

(Date of acceptance : 10 July 1985)

\begin{abstract}
The sodium, potassium, calcium, iron, magnesium and phosphorus contents of the six / Holothurian species Holotburia scabra, Holotburia atra, Holotburia nobilis, Holotburia leucospilota, Bobadscbia marmorata and Sticopus cbloronotus were determined. $H$. scabra has the highest sodium $(4.29 \%)$, potassium $(1.05 \%)$, calcium $(7.91 \%)$ and magnesium $(5.21 \%)$ contents. B. marmorata has the lowest amounts of sodium $(0.30 \%)$ and calcium $(2.05 \%) . H$, atra has the lowest amount of magnesium $(0.73 \%)$ and $S$. chloronotus has the lowest amount of potassium $(0.10 \%)$. $H$. scabra has the highest amount of the trace elements copper (9 ppm) and nickel (36 ppm), while B. marmorata contains the highest amount of manganese $(7 \mathrm{ppm})$ and zinc $(340 \mathrm{ppm})$. Of the two commercial species, $H$, atra $(61-65 \%)$ has a higher protein content than of $H$. scabra. $(36-38 \%)$. The effect of processing on the mineral and protein contents of $H$. atra and $H$. scabra is also reported. Processed $H$. atra and $H$. scabra from the Northern coast of Sri Lanka have a higher protein content $(73-76 \%)$ than the processed $H$. scabra $(59 \%)$ from the South Pacific Islands. A possible method of differentiating $H$. scabra and $H$, atra on the basis of the mineral content is also suggested.
\end{abstract}

\section{Introduction}

The Holothurians are soft, cylindrical-bodied, usually dull dark-coloured and of ten warty species much like cucumbers (therefore called sea cucumbers) belonging to the Invertebrate class Holothuroidea (or Holothurioides) of the phylum Echinodermata. ${ }^{2}$

Holothurians !are marine species of economic importance and their export provides valuable foreign exchange to Sri Lanka. Processed Holothurian, Beche-de-mer is considered a delicacy by the Chinese and as a result is exported to the countries where the Chinese population is relatively high. ${ }^{3}$ The prices of the exported animals depend on qualities such as size, appearance, odour, colour, moisture content and resistance to spoilage. Thus knowledge of the amounts of moisture, protein, carbohydrates, fat, aminoacids and minerals present in different species of Holothurians found in Sri Lanka would be useful in evaluating their food value and the market potential. Holothurians are also used in making poultry feed. ${ }^{3}$ The water extract of $H$. scabra, obtained during processing is used to relieve pain and to cure paralysis by some villagers in the Northern part of Sri Lanka. ${ }^{3}$ 
Of the species known, $H$. scabra is the most commercially popular. In northern Sri Lanka, this species is largely available in the coastal area of Mandaitivu, Nainativu and Mannar. Another commercially popular species $H$. atra is also available in the northern coastal area. The latter is plentiful in the coastal area of Point Pedro.

The mineral, fat, protein and moisture contents of Beche-de-mer processed from $H$. scabra from the South Pacific Islands have been reported. ${ }^{10}$ Recently a group of workers have reported ${ }^{4,5}$ the protein, fat, and saponin contents of some species of Holothurians found in Sri Lanka. In our earlier communication, ${ }^{1}$ we reported the mineral and iodine contents of six species of fresh Holothurians found in the coastal area of Jaffna. In this paper, we report our results on the chemical constituents of the commercially popular species $H$. scabra and $H$. atra along with those of the other species. The effect of processing on the mineral content is also reported.

\section{Experimental Methods and Materials}

Fresh samples of $H$. scabra used in this study were collected from Mandaitivu during the months December 1982 and June 1984 and from Mannar in October 1983. H. atra used for this study was collected from Mandaitivu in March 1983 and June 1984 and from Point Pedro during the months of March and June 1983. Also samples of $B$. marmorata, $H$. nobilis and $S$. chloronotus collected from Trincomalee and $H$. leucospilota collected from Mandaitivu were analysed for comparison purposes. The different species were identified by reported methods. ${ }^{3}$

Processing ${ }^{3}$ of Holothurians was carried out as follows: The specimen was first boiled in water for $30 \mathrm{~min}$ removed from water and allowed to air dry for $3 \mathrm{~h}$. Then the dried specimen was kept under a soil bed overnight for fermentation. The outer body wall cover was removed by washing with water and the processes of boiling and air drying were repeated twice.

After the above treatment, the air-dried samples were dried in an oven $105^{\circ} \mathrm{C}$ to constant weight. The ash content was determined by ashing weighed quantities of oven dried samples at $450^{\circ} \mathrm{C}$ in a Muffle furnace until constant weight was obtained.

\subsection{Preparation of Test Solutions}

Oven dried samples of known weights were ashed at $450^{\circ} \mathrm{C}$ and dissolved (quantitatively) in a known volume of $0.6 \mathrm{M} \mathrm{HCl}$ and the resulting solutions were used to determine sodium, potassium, calcium, magnesium, iron and trace elements. 


\subsubsection{Determination of the Amounts of Sodium and Potassium}

Sodium and potassium contents of test solutions were determined Flame Photometrically ${ }^{7}$ using a Corning 400 Flame Photometer. The Flame intensities for sodium were corrected for interference by calcium by the standard addition method. ${ }^{13}$

\subsubsection{Determination 'of the Amounts of Calcium and Magnesium}

Calcium and magnesium contents of test solutions were determined titrimetrically ${ }^{11}$ using EDTA with potassium cyanide as the masking agent. Patton Reeders indicator was used for calcium determination.

Magnesium content of test solutions was estimated as follows: The total amount of magnesium and calcium present was determined ${ }^{11}$ by titrating a known volume of test solution with standard EDTA solution with Eriochrome Black $\mathrm{T}$ as indicator and using potassium cyanide as masking agent. $^{11}$ Magnesium content was obtained by subtracting the amount of calcium present from this value.

\subsubsection{Determination of Iron}

Iron content of test solution was determined colorimetrically. ${ }^{6}$ $1,10-$ Orthophenanthroline was used as the complexing agent and the colour intensity was measured using a Corning Model 252 Colorimeter with a $490 \mathrm{~nm}$. filter.

\subsubsection{Estimation of Protein Content}

The total nitrogen content of oven dried samples of holothurians was determined by the Kjeldhal method ${ }^{6}$ and protein content was calculated by multiplying the total nitrogen content by 6.25 .

\subsubsection{Determination of Trace Elements}

The trace elements copper, manganous, nickel, zinc, cadmium, cobalt and chromium were determined ${ }^{6}$ using the test solution (prepared as described above) on a Varian Model 1257 Atomic Absorption Spectrophotometer.

\subsubsection{Determination of Lead}

Oven-dried samples were subjected to wet oxidation with concentrated nitric acid and concentrated sulphuric acid as reported previously. ${ }^{6}$ The resulting solution was used to prepare the test solution. The amount of lead present was determined using a Corning Model 252 Colorimeter after complexing with dithizone. ${ }^{6}$ 


\subsubsection{Determination of Phosphorus}

Accurately weighed oven-dried samples $(1-2 \mathrm{~g})$ were ashed with magnesium nitrate ${ }^{6}$ and the ash was dissolved in $1 \mathrm{M} \mathrm{H}_{2} \mathrm{SO}_{4}(10 \mathrm{ml})$ and the solution made up to $50 \mathrm{ml}$. Phosphorus content of this solution was determined ${ }^{6}$ by measuring the intensity of the colour produced on complexing with vanadomolybdate reagent using a Corning Model 252 Colorimeter with 430, 470 and $490 \mathrm{~nm}$ filters.

\subsubsection{Determination of Iodine}

Iodine content of accurately weighed oven dried samples was estimated by the alcoholic potash method. ${ }^{8}$

\subsection{Identification of aminoacids and carbohydrates}

Methanol extracts of fresh samples of $H$. scabra and H. atra were used for the identification of carbohydrates and aminoacids. Carbohydrates and aminoacids were separated from the methanol ex tract by using the cation exchange resin, Zeocarb 225. The aminoacids and carbohydrates present were tentatively identified ${ }^{12}$ by comparing with authentic samples using paper chromatography.

\subsection{Separation of spicules and their analysis}

Spicules were separated ${ }^{3}$ from the flesh of the specimen by adding saturated solution of sodium hypochlorite. The mixture was left overnight and decanted (The spicules will float in the liquid - the flesh will be at the bottom). The spicules were separated from the decanted solution by centrifuging and decanting the supernatant liquid. The spicules were washed with distilled water until no more chloride ions are detected in the washings. The spicules were then weighed, ashed and dissolved in $0.6 \mathrm{M} \mathrm{HCl}$ and the estimation of the minerals were carried out as before.

\section{Results and Discussion}

The habitats of the six holothurian species studied are given in Table 1 and their localities are given in Table 2. Of the six species studied, $H$. atra is the smallest (usually $8-15 \mathrm{~cm}$ in length) and $H$. leucospilota is the largest $(30-80 \mathrm{~cm})$. Our results on the estimation of the amounts of sodium, potassium, calcium and magnesium present in six species of Holothurians are given in Table 3. The amounts of iron, phosphorus and iodine are given in Table 4. Of the six species investigated, H. scabra contains the highest amounts of sodium, calcium and magnesium. But $H$. atra, and the non- 
commercial species $H$. leucospilota and $S$. chloronotus contain relatively high amounts of iron and phosphorus. H. scabra from the Mandaitivu coast and $S$. chloronotus from Trincomalee have appreciable amounts of iodine while $H$. atra, $H$. leucospilota and B. marmorata do not have detectable amounts of iodine. It is interesting to note that seaweeds from the Mandaitivu coast also have high iodine content. ${ }^{9}$ H. scabra from the South Pacific Islands ${ }^{10}$ has higher amounts of sodium and iron than the Holothurian species from Sri Lankan coast but its calcium and phosphorus contents are much lower. Tables 3 and 4 also show the amounts of the same minerals present in different species of Holothurians after processing. Processing removes $87-90 \%$ of sodium and potassium from both $H$. scabra and $H$. atra. Relatively smaller amounts of calcium, magnesium, iron and phosphorus are lost during processing and iodine is lost completely. However there is a large difference in the amount of calcium, magnesium and phosphorus lost by $H$. atra and $H$. scabra. Table 5 gives the percentage of the original amounts of the minerals remaining in the animals after processing to the original value.

Table 1. The habitats of the holothurian species studied.

Species

Holotburia scabra

Holotburia atra

Holotburia leucospilota

Holotburia nobilis

Sticopus cbloronotus

Bobadschia marmorata
Found among eel grasses in the shallow waters and in sandy bottom in deep waters.

Found among coral reefs and clear sand. It is usually found coated with sand with few naked patches.

Found in deep sea (about $10 \mathrm{~m}$ depth).

Found in muddy bottom (4 - $8 \mathrm{~m}$ depth).

Found in deep waters on pebble stone grounds (6-12 $\mathrm{m} \mathrm{depth)}$

Found in deep sandy bottom where the bed can be easily seen from the surface of the water. 


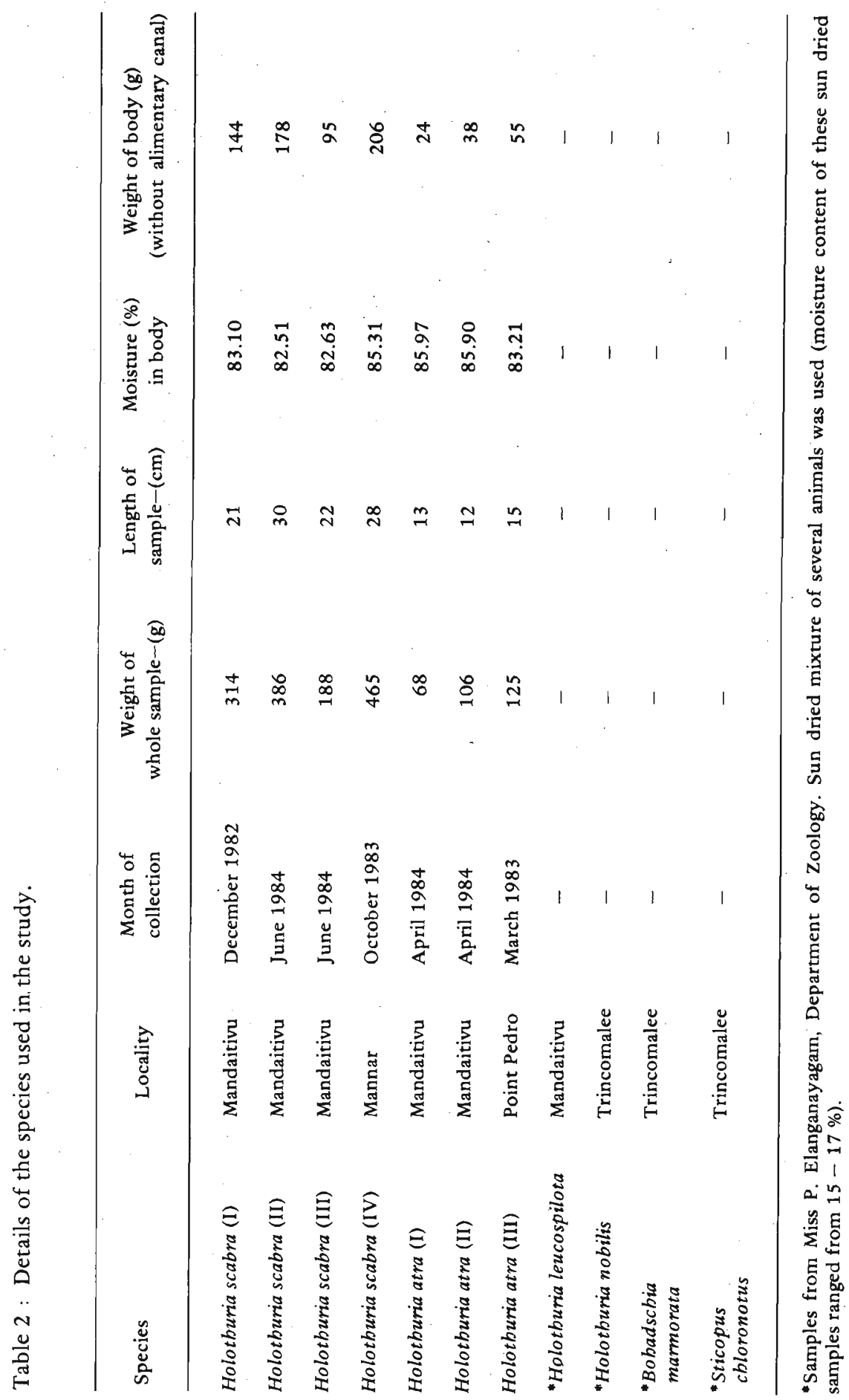




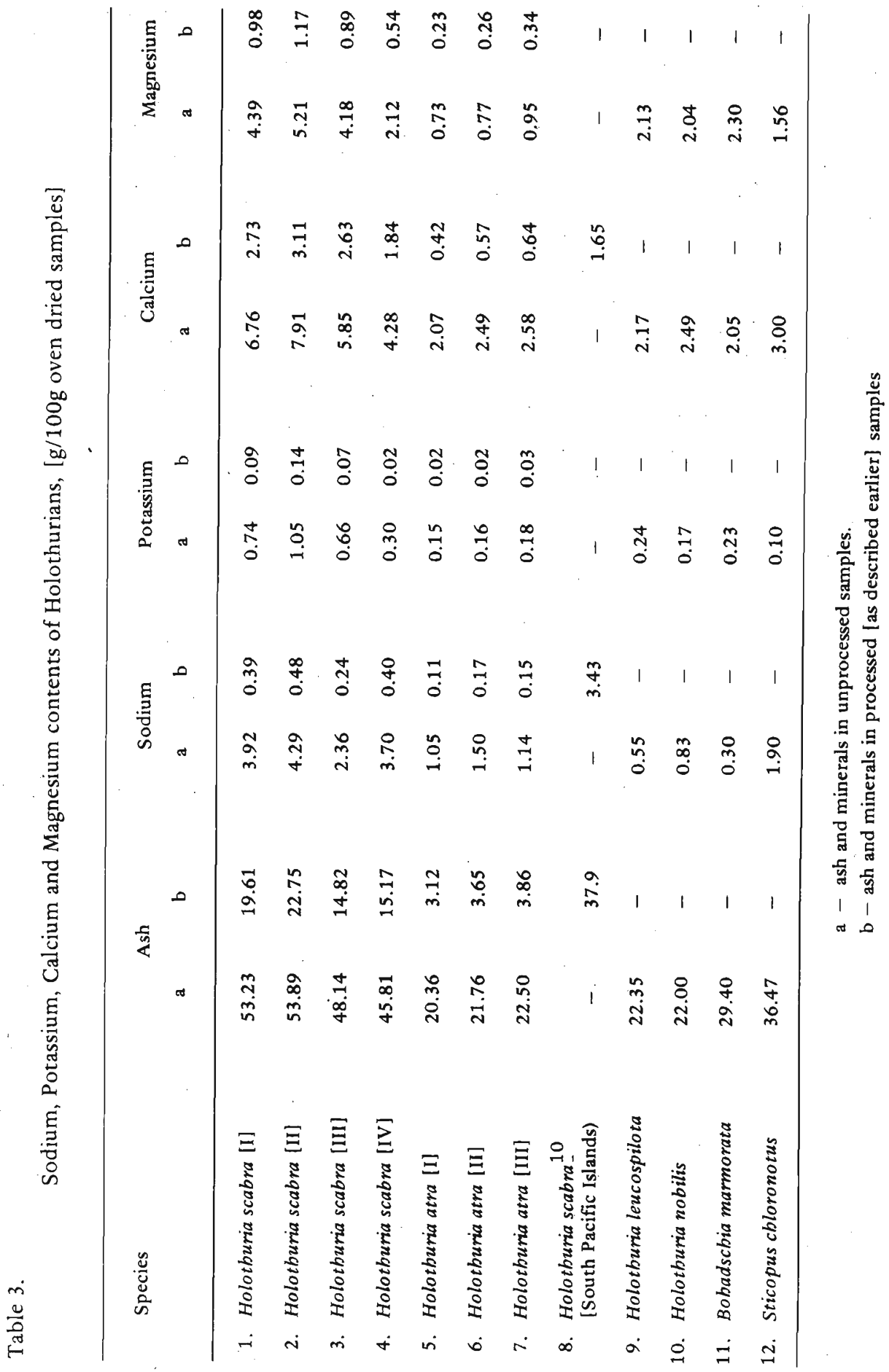


Table 4.

Iron, Phosphorus and lodine contents of Holothurians [ $\mathrm{mg} / \mathrm{kg}$ oven dried samples]

\begin{tabular}{|c|c|c|c|c|c|c|c|c|c|}
\hline & \multirow[t]{2}{*}{ Species } & \multicolumn{2}{|c|}{ Iron } & \multicolumn{2}{|c|}{ Phosphorus } & \multicolumn{4}{|c|}{ Iodine } \\
\hline & & a & b & a & b & 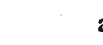 & 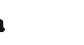 & 'b & \\
\hline 1. & Holotburia scabra [1] & 81 & 43 & 777 & 653 & & 1 & $\begin{array}{l}\text { no dete } \\
\text { amount }\end{array}$ & ctable \\
\hline 2. & Holotburia scabra [II] & 90 & 51 & 865 & 700 & & 4 & $"$ & $"$ \\
\hline 3. & Holotburia scabra [III] & 59 & 31 & 733 & 630 & & 4 & $"$ & $"$ \\
\hline 4. & Holotburia scabra [IV] & 40 & 18 & 281 & 223 & $\begin{array}{l}\text { no dete } \\
\text { amoun }\end{array}$ & ectable & & \\
\hline 5. & Holotburia atra [I] & 146 & 66 & 1092 & 28 & $"$ & $"$ & $"$ & $"$ \\
\hline 6. & Holotburia atra [II] & 233 & 104 & 1116 & 691 & $"$ & $"$ & $"$ & $"$ \\
\hline 7. & Holotburia atra [III] & 452 & 194 & 985 & 625 & $"$ & $"$ & $"$ & $"$ \\
\hline 8. & $\begin{array}{l}\text { Holotburia scabra } 10 \\
\text { [South Pacific Islands) }\end{array}$ & - & 226 & - & 96 & - & - & $\cdot$ & \\
\hline 9. & Holotburia leucospilota & 413 & - & 1255 & - & $\begin{array}{l}\text { no det } \\
\text { amoun }\end{array}$ & ectable & - & \\
\hline 10. & Holotburia nobilis & 336 & - & 666 & - & & 6 & - & \\
\hline 11. & Bobadschia marmorata & 86 & - & 577 & - & $\begin{array}{l}\text { no det } \\
\text { amoun }\end{array}$ & ectable & & . \\
\hline 12. & Sticopus cbloronotus & 251 & - & 1037 & - & 15 & 50 & - & \\
\hline
\end{tabular}

a - minerals in unprocessed samples

b - minerals in processed samples. 
Table 5. Percentage of the original amounts of minerals present after processing.

\begin{tabular}{lcccccc}
\hline Species & $\mathrm{Na}$ & $\mathrm{K}$ & $\mathrm{Ca}$ & $\mathrm{Mg}$ & $\mathrm{Fe}$ & $\mathrm{P}$ \\
\hline Holothuria scabra [I] & 9.9 & 12.2 & 40.4 & 22.3 & 53.1 & 84.1 \\
Holothuria scabra [II] & 11.2 & 13.3 & 42.2 & 22.5 & 56.7 & 80.92 \\
Holothuria scabra [III] & 10.2 & 10.6 & 45.0 & 21.3 & 52.5 & 86.0 \\
Holothuria scabra [IV] & 10.8 & 6.7 & 43.0 & 25.8 & 45.0 & 79.4 \\
Holotburia atra [I] & 10.5 & 13.3 & 20.3 & 31.5 & 45.2 & 57.5 \\
Holotburia atra [II] & 11.3 & 12.5 & 22.9 & 33.8 & 44.6 & 61.9 \\
Holothuria atra [III] & 13.2 & 16.7 & 24.8 & 35.8 & 42.9 & 63.5 \\
& & & & & & \\
\hline
\end{tabular}

One of the reasons for the greater loss of alkali metals during processing could be the higher solubility of their salts. Another possibility is that these salts are present in relatively large amounts in the outer skin and spicules which are removed during the processing. The difference in the loss of calcium, magnesium and phosphorus between $H$. scabra and $H$. atra could be attributed to the difference in the distribution of these elements in the animal body wall, the skin and spicules of $H$. atra containing relatively larger amounts of the minerals than $H$. scabra. Table 6 gives the amount of minerals left in the animal after each stage in processing for the two species H. scabra and $H$. atra.

The trace elements present in different species of holothurians were also estimated using an Atomic absorption spectrophotometer. The elements chromium and cobalt could not be detected in any of the species. The Table 7 shows the amounts of copper, manganous, zinc, lead, nickel and cadmium present in four species. 
Table 6

Effect of processing on the mineral contents of $H$. scabra and $H$. atra; [g/100g oven dried samples]

\begin{tabular}{|c|c|c|c|c|c|c|c|}
\hline $\begin{array}{l}\text { Stage in } \\
\text { processing }\end{array}$ & Ash & $\mathrm{Na}$ & $\mathrm{Ca}$ & $\mathbf{M g}$ & $\mathbf{K}$ & $\mathrm{Fe}$ & $\mathbf{P}$ \\
\hline $\begin{array}{l}\text { 1. Holotburia } \\
\text { scabra }[\mathrm{I}]\end{array}$ & & & & & & & \\
\hline Fresh & 53.23 & 3.92 & 6.76 & 4.39 & 0.74 & 0.0081 & 0.0777 \\
\hline $\begin{array}{l}\text { After 1st } \\
\text { boil }\end{array}$ & 44.10 & 2.95 & 6.04 & 3.05 & 0.447 & 0.0067 & 0.0798 \\
\hline $\begin{array}{l}\text { After } \\
\text { fermentation }\end{array}$ & 33.35 & 1.04 & 4.95 & 2.37 & 0.324 & 0.0084 & 0.0779 \\
\hline $\begin{array}{l}\text { After } \\
\text { 2nd boil }\end{array}$ & 25.69 & 0.47 & 3.28 & 1.27 & 0.210 & 0.0047 & 0.0674 \\
\hline $\begin{array}{l}\text { After } \\
\text { 3rd boil }\end{array}$ & 19.61 & 0.39 & 2.73 & 0.98 & 0.091 & 0.0043 & 0.0653 \\
\hline $\begin{array}{l}\text { 2. Holotburia } \\
\text { atra [II] }\end{array}$ & & & & & & & \\
\hline Fresh & 21.76 & 1.50 & 2.49 & 0.77 & 0.160 & 0.0233 & 0,1116 \\
\hline After 1st boil & 14.32 & 1.23 & 1.74 & 0.49 & 0.093 & 0.0165 & 0.0957 \\
\hline $\begin{array}{l}\text { After } \\
\text { fermentation }\end{array}$ & 7.20 & 0.78 & 1.07 & 0.41 & 0.039 & 0.0180 & 0.0842 \\
\hline After 2nd boil & 4.07 & 0.36 & 0.89 & 0.33 & 0.032 & 0.0140 & 0.0728 \\
\hline After 3 rd boil & 3.65 & 0.17 & 0.57 & 0.26 & 0.020 & 0.0104 & 0.0691 \\
\hline
\end{tabular}




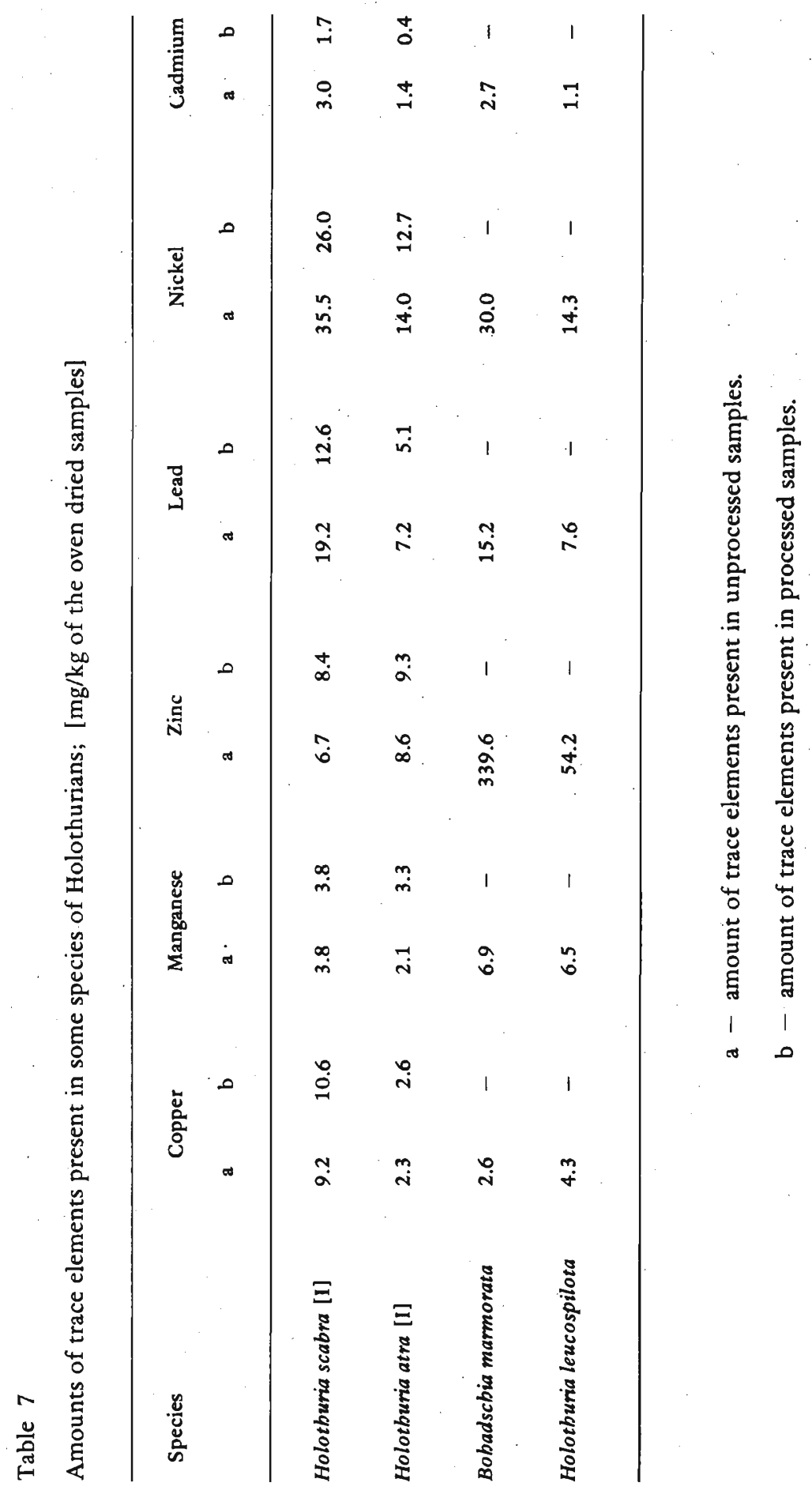


The elements copper, manganous and zinc are essential and nutritive, whereas lead and cadmium are toxic. Elements such as copper and zinc although essential for life in trace amounts, have an toxic action when ingested in higher amounts. The recommended levels of copper and zinc are 20 and $50 \mathrm{ppm}$ respectively. The amounts of copper and zinc present in the commercial species $H$. scabra and $H$. atra are well below the recommended level. The non commercial species $B$. marmorata and $H$. leucospilota contain zinc in quantities well above the recommended level. On processing the percentage of the nutritive elements [Cu, Mn and $\mathrm{Zn}$ ] increases slightly but remain well within the recommended level. The percentage of toxic elements [ $\mathrm{Pb}$ and $\mathrm{Cd}$ ] decreases [by about $30-46 \%$ ] on processing. The mineral contents of the spicules of five species of holothurians are given in Table 8. The spicules of the commercial species $H$. scabra and $H$. atra have a relatively high calcium content. The spicules of $B$. marmorata has relatively high magnesium content while that of $S$. chloronotus is low in calcium but contain the highest amount of potassium and iron. These findings may be of chemotaxonomic significance. It is relevant to note that shape of spicules among other properties is used $^{3}$ in identification of different species of holothurians.

Table 8

Amounts of sodium, calcium, magnesium, potassium and iron present in spicules of different holothurians; [ $\mathrm{g} / 100 \mathrm{~g}$ oven dreid samples]

\begin{tabular}{lccccc}
\hline Species & $\mathrm{Na}$ & $\mathrm{Ca}$ & $\mathrm{Mg}$ & $\mathrm{K}$ & $\mathrm{Fe}$ \\
\hline & & & & & \\
1. Holothuria scabra & 0.74 & 32.20 & 3.21 & 0.0069 & 0.0190 \\
2. Holothuria atra & 0.67 & 34.93 & 4.00 & 0.0012 & 0.0067 \\
3. Bohadschia marmorata & 0.82 & 34.56 & 19.00 & 0.0160 & 0.0270 \\
4. Sticopus chloronotus & 0.21 & 14.03 & 3.84 & 0.0637 & 0.1221 \\
5. Holothuria nobilis & 0.96 & 226.70 & 3.20 & 0.0048 & 0.0066 \\
\hline
\end{tabular}


The protein contents of fresh and processed $H$. . scabra and $H$. atra species are given in Table 9. It is of interest to note that although unprocessed $H$. atra has a very much higher percentage of protein than unprocessed $H$. scabra, the processed species have nearly the same percentage of protein. This may be due to a greater loss of non-protein material from $H$. scabra than from $H$. atra during processing. Also the local $H$. scabra and $H$. atra appear to have higher percentage of protein than the $H$. scabra from South Pacific Islands. 10

The total free aminoacid and carbohydrate contents of $H$. atra and H. scabra have also been estimated by the usual method. The values of the total amount of substances extractable into methanol and the percentages of free aminoacids and carbohydrates present are given inTable 10.

Table 9

Protein contents of fresh and processed Holothuria scabra and Holothuria atra. ( $\mathrm{g} / 100 \mathrm{~g}$ oven dried samples)

\begin{tabular}{lccc}
\hline Species & & & \\
& & Protein & \\
& & Unprocessed & \\
\hline & & & \\
Holotburia scabra [I] & 37.75 & 76.44 \\
Holotburia scabra [II] & 37.10 & 75.02 \\
Holotburia scabra [IV] & 36.69 & 73.31 \\
Holothuria atra [I] & 64.94 & 76.63 \\
Holothuria atra [II] & 63.85 & 76.25 \\
Holothuria atra [III] & 61.44 & 73.50 \\
Holothuria scabra 10 & - & 59.12 \\
[South pacific Islands] & & \\
\hline
\end{tabular}

Table 10. Percentage of free amino acids and carbohydrates

\begin{tabular}{lcccc}
\hline Species & $\begin{array}{c}\text { Weight of } \\
\text { animal/g }\end{array}$ & $\begin{array}{c}\text { Total amount of material } \\
\text { in methanol extract (\%) }\end{array}$ & $\begin{array}{c}\text { Free } \\
\text { amino acids (\%) }\end{array}$ & $\begin{array}{c}\text { Carbohydrate } \\
\text { (\%) }\end{array}$ \\
\hline $\begin{array}{l}\text { Holothuria } \\
\text { scabra } \\
\text { (Mandaitivu) }\end{array}$ & 200 & 3.15 & 0.33 & 0.58 \\
$\begin{array}{l}\text { Holothuria } \\
\text { atra } \\
\text { (Mandaitivu) }\end{array}$ & 56 & 4.70 & 0.45 & 1.37 \\
\hline
\end{tabular}


The carbohydrates present in both the species are in the polysaccharide form, as simple sugars were not detected by chromatographic analysis. Comparative two dimensional paper chromatographic analysis has shown that $H$. atra contains seventeen free aminoacids. Fifteen of them have been identified as aspartic acid, glutamic acid, serine, glycine, threonine, alanine, tyrosine, valine, methionine, histidine, lysine, phenylalanine, arginine, leucine and isoleucine. H. scabra contains fifteen aminoacids. Fourteen of these have been identified as aspartic acid, glutamic acid, serine, glycine, alanine, tyrosine, threonine, valine, arginine, methinine, proline, phenylalanine, leucine and isoleucine. It is interesting to note that $H$. atra contains nine of the ten essential aminoacids whereas H. scabra contains only seven of them.

\section{Conclusion}

Processed H. scabra and H. atra from the coastal area of Northern Sri Lanka have a higher protein content $[73-76 \%$ ] than the processed $H$. scabra from the South Pacific Islands [59.12\%]. Generally $H$. scabra is richer in alkali, alkaline earth and trace metals than $H$. atra whereas the reverse is true in the case of the elements iron and phosphorus. Both $H$. scabra and H. atra have similar $\mathrm{Na} / \mathrm{Ca}$ ratio. But the $\mathrm{K} / \mathrm{Ca}$ and $\mathrm{Mg} / \mathrm{Ca}$ ratios of $H$. scabra are very much higher $[>60 \%]$ than those of $H$. atra. Thus it is possible to differentiate $H$. scabra and $H$. atra on the basis of the mineral constituents. Processing increases the protein content and the amounts of copper, manganese and zinc and decreases the alkali, alkaline earth and toxic elements.

\section{Acknowledgement}

The authors wish to thank Miss. P. Elanganayagam, Depratment of Zoology for providing samples of some holothurians and Messers. M. Ariyaratnam and N. Baskaran for technical assistance.

\section{References}

1. BALAKRiShNAN, V. \& MAGESWARAN, R., (1983) Proc. I. Chem. C 12, 13.

2. BARNES, R. D,(1974) Invertebrate Zoology (Third Edition), W.B. Saunders Company, 724.

3. ELENGANAYAGAM, P., (1983) M. Phil thesis. 
4. ELANGANAYAGAM, P., GANESHALINGAM, V. K. \& SACHITHANANTHAM, K. (1980) Proc. Sri Lanka Ass. Advmt. Sci. 36, 62.

5. ELANGANAYAGAM, P., MAHENDRAN, M., KRISHNARAJAH, S.R., GANESHALINGAM, V. K. \& SACHITHANANTHAM, K, (1982) Proc. I. Chem. C. 11,5 .

6. JACKSON, M. L, (1973) Soil Chemical Analysis, Prentice-Hall of India Ltd., New Delhi pp. $151-154,336,389$.

7. JACOBS, M. B, (1958) The Chemical Analysis of Foods and Food Products, D. Van. Nostrand Co. New York.

8. KAPPANNA, A. N. \& RAO, V. S, (1962) J. Sci.\& Ind. Res. 21 B 559.

9. MAGESWARAN, R. \& SiVASUBRAMANIAM, S.,(1984) J. Natn. Sci. Coun. Sri Lanka 12 (No. 2). 173.

10. SACHITHANANThaM, K., (1973) South Pacific Islands, Beche de-mer fishery, Food and agriculture organisation of the United Nations; Rome.

11. SAHAI; D.N. (1974) Technology, 11 pp. $420-422$ \& Chenery, E. M.,(1964) The Analyst 89 pp. $365-367$.

12. SMITH, I. \& SEAKINS, J. W. T., (1976) Chromatographic and Electrophoretic Techniques (1), William Heinemann Medical Books Ltd., 84.

13. WILlARD, H. H., MERRITT, L. L. \& DEAN, J. A., Instrumental Methods of Analysis, Van Nostrand Reinhold Company, 342. 